\title{
Creating a Conducive Environment for SMEs in Sri Lanka
}

\author{
PRETHEEBA, $\mathrm{P}$. \\ Department of Business and Management Studies \\ Eastern University of Sri Lanka \\ SRI LANKA \\ p.pretheeba@gmail.com
}

\begin{abstract}
:-
Small and Medium Enterprises (SMEs) have been recognized as an important strategic sector especially among the developing countries. This paper intends to study the development of SMEs in Sri Lanka compared with developed Asian country of Singapore. The paper further reviews the empirical studies in order to identify the major contributions and challenges faced by the country. The key message from the study is that Sri Lanka faces several challenges include the absence of adequate and timely finance, limited capital and knowledge, nonavailability of suitable technology, low production capacity, constraints on modernization and expansions, non availability of highly skilled labour at affordable cost, follow-up with various government agencies to resolve problems etc. However, Singapore have technical trade barriers, high operating and labour cost, and intense competition, the SMEs of the country sharpened by ongoing government support, a robust infrastructure, a strong financial sector and myriad schemes aimed at developing a pro-enterprise environment. The government of Singapore is seized of the issues and earnestly trying to encourage effective and creative business development. This paper attempts to identify the challenges and offer a few suggestions towards formulating a workable framework for the SMEs in Sri Lanka.
\end{abstract}

\section{Key Words:-}

Performance, Economic Growth, SMEs, Challenges, Environment 


\section{Background of the Study}

Small and Medium Enterprises (SMEs) are the backbone of the economies, because it trigger employment, output, export, poverty alleviation, economic empowerment, economic development, etc in developed as well as in developing countries. It is more important to developing countries as the poverty and unemployment are burning problems. rated as the most business-friendly economy and also considered as the fasterest growing economy in the world (The Economic Times, 2010). As a partner of Colombo plan Singapore developed themselves better than Sri Lanka.

Table 1: Contribution of SMEs in Selected Diverse Economies for the period of $2005-2008$

In developing Asia, SMEs have made significant contributions over the years measured in terms of their share in number of enterprises, employment, production and value added, GDP, and regional dispersal of industry, among others. The contribution of SMEs is vital in as much as they make up $80-90 \%$ of all enterprises, provide over $60 \%$ of the private sector jobs, generate $50-80 \%$ of total employment, contribute about $50 \%$ of sales or value added, and share about $30 \%$ of direct total exports (Narain, 2003). Table - 1 illustrates the contribution of small business ventures across various Asian economies.

Among the countries in the table - 1, Singapore is the strongest-growing

\begin{tabular}{|l|c|c|c|}
\hline Country & $\begin{array}{l}\text { Share of } \\
\text { Total } \\
\text { establish } \\
\text { ment }\end{array}$ & $\begin{array}{l}\text { Share } \\
\text { of } \\
\text { Emplo } \\
\text { yment }\end{array}$ & $\begin{array}{l}\text { Share of } \\
\text { Output }\end{array}$ \\
\hline India & $95 \%$ & $70 \%$ & $39 \%$ \\
Sri Lanka & $90 \%$ & $70 \%$ & $20 \%$ \\
Japan & $99 \%$ & $70 \%$ & $51 \%$ \\
Taiwan & $98 \%$ & $70 \%$ & $45 \%$ \\
Singapore & $99 \%$ & $62 \%$ & $49 \%$ \\
Korea & $99 \%$ & $69 \%$ & $46 \%$ \\
Thailand & $99 \%$ & $76 \%$ & $47 \%$ \\
Malaysia & $99 \%$ & $55 \%$ & $47 \%$ \\
\hline
\end{tabular}
Sources: India (FISME); Sri Lanka (Ministry of Finance and Planning, 2010); Japan (JASME, 2007, Small and Medium Enterprise Agencies); Taiwan (White Paper on SMEs in Taiwan, 2006); Singapore (DOS, 2007), Korea (UNESCAP), Thailand (White Paper on economy in Asia for the year 2010 and probably in the world. The country is

SMEs in Thailand, 2002), and Malaysia (UNDP, 2007). 
However including Singapore, in many parts of the world existence of SMEs are high in numbers but their performances have not been much impressive; but large businesses are few, their achievements in terms of output are highly significant. Table -1 shows, the performance of SMEs remains weak in all Asian regions, especially in Sri Lanka. Even though Sri Lanka has the needed resources its achievement in SMEs is far below than other economies.

Hence it is important to examine the problems/ constraints that SMEs are facing in Sri Lanka and identify the practical means to improve the environmental performance. In order to develop the SME sector of the countries, it is important to look in to actions and strategies adopted in neighboring counties particularly in Asian region. Therefore, the study considers Singapore as a model to give suggestions to Sri Lanka.

\section{Analysis of Factors Influency Entrepreneurship}

\subsection{Market Entry}

The first critical stage in development of an SME is market entry. This includes all steps and procedures in starting a business and run in compliance with the laws and regulations of the country. There are two important factors in this regard: the time takes to start a business and the cost.

World Bank \& IFC (Doing Business, 2010) ranked Singapore in $4^{\text {th }}$ place for starting a business, which is the highestranked country in Asia to do business, where Sri Lanka ranked $34^{\text {th }}$ position among 183 countries. Entrepreneur in Singapore can start a business within 03 days with 03 procedures (Cost SGD 385), but for the same business the entrepreneur need more than a month of time in Sri Lanka (35 days). The main reason for delay in Sri Lanka, is authorities like Department of Inland Revenue of Sri Lanka, Ministry of Labour, etc takes more than a month to comply procedures.

These are not the only obstacle to SMEs. SMEs are constrained by inadequate supply of infrastructure, access to financing, tax regulations, inadequately educated workforce, corruption, inefficient government bureaucracy, restrictive labour regulations, etc (Global Competitiveness Report, 2010/2011). 


\subsection{Infrastructure}

Extensive and efficient infrastructures such as power, water, roads, sewers, etc. are essential for economy growth. The businesses in Sri Lanka suffer by poor quality of infrastructures. The availability and accessibility are the weakest part of infrastructure in Sri Lanka. Sri Lanka, and Singapore ranked $70^{\text {th }}$ and $5^{\text {th }}$ position respectively in provision of infrastructure (Global Competitiveness Report 2010 / 2011).

\subsubsection{Electricity}

Economies need continuous supply of electricity, which enable businesses and factories to work without any interruption. Sri Lanka and Singapore ranked $76^{\text {th }}$ and $9^{\text {th }}$ position respectively in supply of quality electricity (Global Competitiveness Report 2010 / 2011).

Singapore has the best electricity and gas networks in the world. International industry indices rated the country as the fewest and shortest outage city in worldwide. The System Average Interruption Duration Index (SAIDI), which measures the average duration of unplanned interruptions a customer experiences a year was 0.31 (Sri Lanka 4.68) minutes for the electricity grid for the year 2009/2010 (Ben Lobel, 2010;
Power Electrical \& High Voltage Engineering).

Challenges Sri Lanka faces in power sector are, high cost generation, transmission and distribution, and poor governance which cause severe constraints on reliable and quality supply of electricity. Generation cost in Sri Lanka exceeds $80 \%$ of the total cost of the sector. It is higher than the cost experienced by other countries in the region (http://sanvada.org, 2009).

The high frequency of interruptions increases the cost of output, because power disruptions cause damage to materials in-process, equipments, and intensify maintenance and repair costs. In response to power shortages, businesses run their own generators; the unit costs of additional power generated by such industries are higher than the supply from the public grid which is reliable and economical. Apart to this, enterprises pay high amount tariffs for power consumption from the public grid in Singapore and Sri Lanka.

\subsubsection{Transportation}

Effective transport infrastructure includes quality roads, rail road, port, and air transport which enable entrepreneurs to get their goods and 
services to market in timely manner and reduce the cost of business operation.

Table - 02 Transportation (Rank)

\begin{tabular}{|l|c|c|}
\hline \multicolumn{1}{|c|}{ Elements } & Singapore & $\begin{array}{c}\text { Sri } \\
\text { Lanka }\end{array}$ \\
\hline $\begin{array}{l}\text { Quality of } \\
\text { roads }\end{array}$ & 01 & 55 \\
\hline $\begin{array}{l}\text { Quality of } \\
\text { railroad }\end{array}$ & 06 & 40 \\
\hline $\begin{array}{l}\text { Quality of port } \\
\text { Quality of air } \\
\text { transport }\end{array}$ & 02 & 64 \\
\hline
\end{tabular}

(Source: Doing Business, World Bank \& IFC, 2010/2011)

The world-class roads, port, and air transport facilities, aid cost effective freight in Singapore. In Sri Lanka road, rail road, port and air transport conditions and standards are inadequate to meet rapidly growing freight and passenger traffic (World Bank, 2011).

\subsubsection{Telecommunication}

Singapore was one of the first countries in the world have a fully digital telephone network built with competitive telecoms market, aided by excellent geographical location and infrastructure. The World Economic Forum has described Singapore as 'Asia's most connected country', noting that it was leading the region in terms of ICT development (http:// www.budde.com. au, 2010). The availability and affordability of telecoms in Sri Lanka are far below than Singapore telecommunication facility.

\subsection{Technology Readiness}

In todays globalize world, technology is a vital element for entrepreneurs to compete and prosper in an intensive competition.

As per the elements in table - 03, World Bank \& IFC ranked the technology readiness of Singapore and Sri Lanka in $86^{\text {th }}$ and $84^{\text {th }}$ place respectively. In labor scarce Singapore, technology is an essential tool to reduce production costs, cut down dependency on labor, ensure consistency in quality, and increase flexibility of production.

In Sri Lanka availability of latest technology, firm's readiness to espouse technology and technology transfer in SMEs are far behind than Singapore. 
Table - 03 Technology Readiness (Rank)

\begin{tabular}{|l|c|c|}
\hline \multicolumn{1}{|c|}{ Elements } & Singapore & $\begin{array}{c}\text { Sri } \\
\text { Lanka }\end{array}$ \\
\hline $\begin{array}{l}\text { Availability of } \\
\text { latest } \\
\text { Technology }\end{array}$ & 20 & 61 \\
\hline $\begin{array}{l}\text { Firm - level } \\
\text { technology } \\
\text { adoption }\end{array}$ & 15 & 47 \\
\hline $\begin{array}{l}\text { FDI and } \\
\text { technology } \\
\text { transfer }\end{array}$ & 03 & 49 \\
\hline Internet users & 16 & 106 \\
\hline $\begin{array}{l}\text { Broadband } \\
\text { internet } \\
\text { subscriptions }\end{array}$ & 22 & 95 \\
\hline $\begin{array}{l}\text { Internet } \\
\text { bandwidth }\end{array}$ & 14 & 97 \\
\hline
\end{tabular}

(Source: Doing Business, World Bank \& IFC, 2010/2011)

\subsection{Financial Market}

Entrepreneurs require sophisticated financial markets which make capital available from various sources such as loans from sound banking sector, properly regulated securities exchanges, venture capital and other financial sources to succeed in business activities.
Table-04 Financial Market Sophistication

\begin{tabular}{|l|c|c|}
\hline \multicolumn{1}{|c|}{ Elements } & Singapore & $\begin{array}{c}\text { Sri } \\
\text { Lanka }\end{array}$ \\
\hline $\begin{array}{l}\text { Availability of } \\
\text { financial } \\
\text { services }\end{array}$ & 02 & 48 \\
\hline $\begin{array}{l}\text { Affordability of } \\
\text { financial } \\
\text { services }\end{array}$ & 05 & 42 \\
\hline $\begin{array}{l}\text { Financing } \\
\text { through local } \\
\text { equity }\end{array}$ & 05 & 17 \\
\hline $\begin{array}{l}\text { Ease of access to } \\
\text { loans }\end{array}$ & 04 & 33 \\
\hline $\begin{array}{l}\text { Venture capital } \\
\text { availability }\end{array}$ & 03 & 62 \\
\hline $\begin{array}{l}\text { Restriction on } \\
\text { capital flows }\end{array}$ & 06 & 67 \\
\hline $\begin{array}{l}\text { Soundness of } \\
\text { banks }\end{array}$ & 09 & 37 \\
\hline $\begin{array}{l}\text { Regulation of } \\
\text { securities } \\
\text { exchanges }\end{array}$ & 03 & \\
\hline $\begin{array}{l}\text { Legal rights } \\
\text { index }\end{array}$ & 01 & \\
\hline
\end{tabular}

(Source: Doing Business, World Bank \& IFC, 2010/2011)

Financial market sophistication of Singapore and Sri Lanka are ranked $17^{\text {th }}$ and $52^{\text {nd }}$ position respectively (World Bank \& IFC 2010/2011). Even though Singapore ranked for healthy financial market, the soundness of bank is weak compare to other elements. However in recent years institutions encourage "angel investment" an alternative venture capital method to succeed in businesses. 
Sri Lanka undergo costly and limited finance access. Major portion of rural entrepreneurs' investment finance is from internal sources, since the private commercial banks play a very limited role. Family and friends are the main external sources beside internal.

\subsection{Labour Market Efficiency}

Table - 05 Labour Market Efficiency (Rank)

\begin{tabular}{|l|c|c|}
\hline \multicolumn{1}{|c|}{ Elements } & Singapore & $\begin{array}{c}\text { Sri } \\
\text { Lanka }\end{array}$ \\
\hline $\begin{array}{l}\text { Cooperation in } \\
\text { labour } \\
\text { employer } \\
\text { relations }\end{array}$ & 01 & 64 \\
\hline $\begin{array}{l}\text { Flexibility of } \\
\text { wage } \\
\text { determination }\end{array}$ & 03 & 72 \\
\hline $\begin{array}{l}\text { Rigidity of } \\
\text { employment }\end{array}$ & 01 & 48 \\
\hline $\begin{array}{l}\text { Hiring and firing } \\
\text { practices }\end{array}$ & 02 & 94 \\
\hline $\begin{array}{l}\text { Redundancy } \\
\text { costs }\end{array}$ & 06 & 133 \\
\hline $\begin{array}{l}\text { Pay ayd } \\
\text { productivity }\end{array}$ & 01 & 40 \\
\hline $\begin{array}{l}\text { Reliance } \\
\text { professional on } \\
\text { management }\end{array}$ & 09 & 31 \\
\hline Brain drain & 04 & 51 \\
\hline $\begin{array}{l}\text { Female } \\
\text { participation in } \\
\text { labour force }\end{array}$ & & 108 \\
\hline
\end{tabular}

(Source: Doing Business, World Bank \& IFC, 2010/2011)
Singapore is placed $1^{\text {st }}$ for labor market efficiency, where Sri Lanka stands in $104^{\text {th }}$ places (World Bank \& IFC 2010/2011). Management of the workforce is a difficult task for many Singapore entrepreneurs due to labour shortage and difficulty in obtaining foreign workers. The female participation in labour forces also one of the weak parts than other human resource elements. Boey and Chiam Lee (1994) viewed that the economic growth of Singapore is favorable for businesses, even though Singapore SMEs face potential threat from availability of cheaper labour and raw materials from their/neighboring countries.

Abeywickrema (2005) said that the education system in Sri Lanka does not make skillful youths for employment. He further stated, high transaction cost, lack of field officers, poor availability of financial services, accessibility and affordability are some of the major challenges faced by Sri Lanka entrepreneur in development of efficient labour market. 
3. Discussions on

Entrepreneurship Business

Environment

Table - 06 Entrepreneur Business

Environment Singapore and Sri Lanka
Authority issue notice of incorporation via e-mail to law and/or professional firms engaged for the purposes of incorporation, with the registration number of the company. The registration with the Inland Revenue Authority of Singapore (IRAS) for the Goods and Services Tax (GST) is also

\begin{tabular}{|c|c|c|}
\hline $\begin{array}{l}\text { Successive } \\
\text { Elements }\end{array}$ & Singapore & Sri Lanka \\
\hline Market Entry & Easy & $\begin{array}{l}\text { Time } \\
\text { Consume }\end{array}$ \\
\hline $\begin{array}{l}\text { Infrastructure } \\
\text { Electricity } \\
\text { Generation } \\
\text { Distribution } \\
\text { Transportation } \\
\text { Telecommunication }\end{array}$ & $\begin{array}{l}\text { Adequate } \\
\text { Good } \\
\text { Adequate } \\
\text { Best }\end{array}$ & $\begin{array}{l}\text { Adequate } \\
\text { Poor } \\
\text { Inadequate } \\
\text { Weak }\end{array}$ \\
\hline $\begin{array}{l}\text { Technology } \\
\text { readiness }\end{array}$ & Adequate & Inadequate \\
\hline $\begin{array}{l}\text { Financial Market } \\
\text { Sophistication }\end{array}$ & Good & Very Poor \\
\hline Labour Market & Good & Very Poor \\
\hline
\end{tabular}
possible via online. The utilization of technology reduces the time, effort, and cost for entrepreneur as well as the authorities (World Bank 2009).

Number of procedures and/or cost is not an issue to start a business in Sri Lanka, but the time duration taken to start a business is high, because of the labor-intensive work process in authorities such Registrar of Company, Department of Inland Revenue of Sri Lanka, Ministry of Labour, etc,. Further authorities do not integrate within themselves.

\subsection{Market Entry}

In Singapore, enterprise incorporations held through Bizfile (an electronic filing system), which reduces number of days and cost to start a business. Entrepreneurs submit application for approval and registration of a company via Bizfile, which complete within an hour after online payment. The Accounting and Corporate Regulatory
Hence entrepreneurs have to visit different places to comply their requirements.

\subsection{Infrastructure}

\subsubsection{Electricity}

Singapore has adequate electricity generation with minimum transmission and distribution problem. Mr. Sim Kwong Mian, Managing Director of SP 
Power Grid (2010) said, Singapore Power's grid attains high level of performance excellence via new technology which enable them to continue on network performance and cost-effective improvements. Staff motivation for innovative ideas, in the form of process improvements or new applications in existing technology result more efficient operations, higher productivity, and safety.

High-cost generation and distribution are downsides in supply of electricity in Sri Lanka. The deviation from the longterm generation expansion plan owing to political decisions cause delays in low cost generation. Another issue in Sri Lanka, the sales of electricity below cost of supply and the burden of debt create disincentive for energy sector to expand access to the grid or off-grid services to the villages. Moreover, there are delays in implementing the plan for expanding least-cost generation capacity and reliance on ad-hoc purchases of emergency power.

\subsection{Transportation}

Singapore has the first class express high-ways, rail road, air transport and ports. Mass rapid transit, buses, and taxis are the three main modes of public transport. Public buses serve almost every part of Singapore which is the most extensive form of public transportation, while the MRT provides speed and efficiency, especially during peak hours. The ez-link card is an innovation that was added to both the bus and rail network in Singapore.

The weaknesses in Sri Lanka transportation are low high ways capacity, lack of express ways to connect major economic centers, neglected maintenance, lack of official capacity, and resources which lead to severe deterioration of roads. Poor condition and deteriorated services of rail road also hinder the development of entrepreneurship.

\subsubsection{Telecommunication}

The telecommunication network in Singapore comprises of a modern pushbutton network. Optic fiber links the 29 telephone exchanges in the state. The complete digitalization of the system makes way for a broader range of service. There are 1.31 Direct Exchange Lines (DELs) in Singapore. Since it removes barriers for foreign entry to the telecommunications sector, any foreign or domestic companies provide facilities-based or services-based telecom services. There is no foreign equity limits imposed on telecommunication licensees. Telecom service providers have the freedom to 
interconnect with networks on terms and conditions and with cost-oriented rates that are transparent and reasonable.

There are some problems remain in Sri Lanka telecommunications even though it is one of the fastest growing sectors. Sri Lanka outperforms South Asian countries in teledensity, though there is great scope for improvement. The average waiting time for phone connections and cost are high. Mobile companies have the latest technology, even though it faces technology problems such as capacity limitations, limited spectrum for microwave links, problems in extending fiber networks to base station, and power availability issues. Further Ashoka Feranando (2007) finds the telecommunication governance has been performing under a plethora of constraints: institutionally the regulator is affected by its own internal problems, politicians have become exceptionally powerful, affecting every function of the regulator, and legal provisions have proven inadequate limiting the power of the regulator.

\subsection{Technology}

Numbers of incentives have been introduced in Singapore to accelerate the tempo of automation in SMEs; The
National Computer Board (NCB) undertakes promotional and informational work on IT, training and education, the establishment of sectorwide IT network, and provision of assistance for computerization. The Government of Singapore encourages entrepreneurship by the way of grants, consultancy, and networking support (SPRING; Dec, 2010).

The studies in Sri Lanka revealed number of technology inhibitig factors for business ventures: lack of knowledge and awareness about benefits of e-commerce, unpreparedness of SMEs to adopt ecommerce as a serious business concept, inadequate publicity to IT products and services, and lack of staff with IT capability (SLBDC, 2002). Web-based selling was not seen as practical; as there is limited use of Internet banking, and Web portals, as well as inadequate telecommunications infrastructure (SLBDC, 2002). Mahesh.K and Robyn. L (2007) suggested various internal and external factors cause barriers for the adoption of ICT in SMEs in Sri Lanka. The study found cultural (lack of popularity for online marketing and sales), infrastructure (low internet penetration in the country, inadequate quality and speed of lines), political 
(unstable economic climate, changing regulations with the changing governments), social (lack of information on e-commerce, no oneshop facility, no access to reliable expert help), and legal (little support for SMEs from government and industry associations, inadequate legal framework for business using ecommerce, no simple procedures and guidelines, and lack of suitable software standards) barriers for the adoption of ICT in SMEs.

\subsection{Financial Market}

Singapore's markets for securities, derivatives, and currencies are highly developed and they provide regional services. The facilities that banks grant range from overdrafts and short-term advances to medium and long-term loans. They also grant import and export financing facilities, include letters of credit, discounting of bills of exchange, trust receipt financing and acceptance financing. Some banks assist customers in raising funds directly from investors and other banks and underwriting any amounts that are not taken up by such investors and banks. There are no interest cartels in Singapore. All banks, merchant banks and finance companies are free to quote the interest they pay for deposits or charge for credit facilities. Even though capital is readily available through bank credit, equity sales, and corporate debt issues, SMEs and start-ups complain of inadequate in finance access. In 2010 Singapore introduces an alternative venture capital method called angel investment (Grant Thornton 2010; SPRING 2010).

Surveys from Sri Lanka revealed that SMEs have difficulty in borrowing from formal credit channels in view of their inability to present bankable proposals due to limited knowledge and skills in financial management and operational governance. Although several financial schemes launched in Sri Lanka to improve access to finance for SMEs', inadequate collateral, high interest rates, demanding guarantee requirements, difficult procedures for getting loans, bank's unwillingness to provide adequate working capital, unsuited offers from the banks to SMEs needs, and the view that banks do not want to take risks in lending to SME companies are the problems for the SMEs (Sharmini De Alwis and B. M. R. Basnayake, 2008). On the other hand the bank networks coverage also a constraint to entrepreneurs for adequate credit finance access. 


\subsection{Labour Market Efficiency}

In Singapore, labour market efficiency is achieved with the strong efforts of the Ministry of Manpower (MOM) (SPRING; Dec, 2010). MOM plays an integrating role with unions and employers to build harmonious workplace relations. This has enabled Singapore to remain strike-free since 1986. Singapore's strong labouremployer relations was particularly evident during the 2008/2009 global economic downturn when MOM and its tripartite partners worked swiftly to help companies cut costs and save jobs through programmes such as the Jobs Credit Scheme and Skills Programme for Upgrading and Resilience (SPUR) (SPRING; Dec, 2010). SPRING launched the Business Leaders Initiative (BLI) which is a comprehensive leadership framework aimed at developing business leaders at every level of the organization to help the SMEs groom leaders for their success. Further universities actively involved in developing postgraduates and executive development courses, aimed at enabling and empowering business owners / top executives of SMEs with relevant knowledge and skill-sets to take their businesses to the level of multi-national enterprises.
Enterprises become uncompetitive in Sri Lanka since the inflation pushes cost of labour. The education system in Sri Lanka make students just memorize and rehearse during examination, which suppress creativity, innovation, and entrepreneurial spirit in development of skilled employees.

\section{Conclusions}

Based on analysis and discussion study conclude Singapore has excellent telecommunications network, infrastructure, first-class transportation and information technology, all these made country to become an ideal location for SMEs. However to be more effective environment needs sufficient financial assistance, training, and advisory services.

The SME sector in Sri Lanka shares similar problems to those of some Asian countries. This study clearly states that technology, infrastructure, financial market, and labour skill are pathetic in Sri Lanka. The supports for the concerned areas need to be improve though government policies and regulation for the development of SMEs in Sri Lankan. 


\section{Recommendations}

- Government / funding agencies of Sri Lanka should allocate additional fund in budget for the development of infrastructure.

- Sri Lanka should identify the potential of wind power plant and other alternative non conventional source of power generation.

- Sri Lanka should initiate and encourage angel funding for the development of SMEs.

- SME support institutions should create awareness and develop skills on preparing bankable proposals for financing.

- Reduce interest rate, collateral, procedures and guarantee requirement for SME finance requirements.

- Sri Lanka should extend bank networks to rural areas for the effective functioning of SMEs.

- Internet/Telecommunication service providers of Sri Lanka should introduce cost effective services.

- Government of Sri Lanka should encourage private sector participation in the process of framing SMEs policy and administrative reforms.

- Government of Sri Lanka should introduce myriad schemes for the development of pro-enterprise business environment like Singapore.

- Sri Lanka should move from uniformity to diversity, conformity to resilience and orienting towards a creative educational system.

\section{References}

ADB (2007), "Report and Recommendation of the President to the Board of Directors - Proposed Loan Democratic Socialist Republic of Sri Lanka: Small and Medium Enterprise Regional Development Project", http://www.adb.org/documents/rrps/sri/ 36117-sri-rrp.pdf, retrieved on 20 - 07 2011.

Andrew L S Goh, "Towards An Innovation-Driven Economy Through Industrial Policy-Making: An Evolutionary Analysis Of Singapore", The Public Sector Innovation Journal, Volume 10(3), article 34

Asoka Fernando, (2007), "Building Better Governance: The Case of Sri Lanka Telecommunications Industry 
Reforms", http://www.cprsouth.org/wpcontent/uploads/drupal/Asoka\%20Ferna ndo.pdf, retrieved on $22-07-2011$.

Balbir B. Bhasin (2007), "Fostering Entrepreneurship: Developing a Risktaking Culture in Singapore", http://www.balbirbhasin.org/documents/ NEJE\%20Bhasin-Fall07-3.pdf, retrieved on $23-06-2011$.

Bandula Sirimanna, "Sri Lankan banks ease SME loan terms, but few do for collateral”, http://sundaytimes.lk / 110619/BusinessTimes/bt32.html, retrieved on $12-06-2011$.

Ben Lobel (2010), "Leading Asia Pacific energy utility firm", http://www.businessrevieweurope.eu/ company-reports/singapore-power, retrieved on $12-07-2011$.

Blanchflower, D.G. (2000), "Selfemployment in OECD countries", Labor Economics, 7, 471-505.

DBS Bank Lts, (2008), "Financing SMEs - The Singapore Experience", http://www.adb.org/documents/rrps/sri/ 36117-sri-rrp.pdf - $05-2011$.

Federation of Chambers of Commerce and Industry of Sri Lanka, "SME Access to Finance Program", http://www.fccisl.lk/index.php?option= com_content\&task
$=$ view $\& \mathrm{id}=573 \&$ Itemid $=38, \quad$ retrieved on $13-07-2011$.

Gamini De Alwis W.P \& Senathiraja R (2003), "The Impact of Socio - Cultural background of the Entrepreneur on Management and Business Practices of Selected Small and Medium Scale Business in Sri Lanka", 9th International Conference on Sri Lanka Studies.

Grant Thornton, "Doing Business in Singapore", http://www.gt.com.sg/ publications/articles/Doing\%20Business $\% 20 \% 20 \mathrm{in} \% 20$ Singapore.pdf, retrieved on $04-07-2011$.

Lalitha. R, Fernando.S, "Entrepreneurship in Delivery of Service in Public Sector Organization in Sri Lanka: Prospects for Administrative and Managerial Reforms", http://www.napsipag.org/pdf/Entreprene urship_Service.pdf, retrieved on $13-07$ $-2011$.

Ministry of Finance and Planning Sri Lanka (2010), "Crisis Response SME Development Facility (SMEDeF) Volume 1", http://www.treasury.gov.lk/ FPPFM/ddf/pdfdocs/envirmentvol1.pdf, retrieved on 28 - 05 -2011.

Office of Small and Medium Enterprises Promotion, "White Paper on 
Small and Medium Enterprises in Thailand 2002", http://www.sme.go.th/SiteCollectionDo cuments/White\%20Paper/2545/whitepa per_2545_Eng.pdf, retrieved on 28 - 05 $-2011$.

Power Electrical \& High Voltage Engineering, "Distribution Planning", http://etrical.wordpress.com/distribution -planning/, retrieved on $10-08-2011$.

Priyanath H.M.S, (2006), "Managerial Deficiencies in the Small and Medium Enterprises (SMEs) in Sri Lanka: An Empirical Evidence of SMEs in the Ratnapura District", Sabaragamuwa University Journal, vol 6, no. 1 pp 93105.

Schaper, M., \& Volery, T. (2007), "Entrepreneurship and small business:

A Pacific Rim perspective" (2nd Edition). Milton, QLD: John Wiley \& Sons Australia, Ltd.

Sharmini De Alwis and B. M. R. Basnayake, (2008), "Credit Guarantee Schemes in Sri Lanka - Way forward", http://www.smeg.org.tw/doc/JSD-143.pdf, retrieved on 15-07-2011.

Singapore Department of Statistics, http://www.singstat.gov.sg/pubn/busine ss/sme2007.pdf, retrieved on 28 - 05 2011.
Small and Medium Enterprise Agencies (2007), http://www.chusho.meti.go.jp/ sme_english/outline/07/01.html, retrieved on 28 - 05 - 2011.

Small and Medium Enterprise Administration, Ministry of Affairs (2010), http://www.moeasmea.gov.tw/l p.asp?ctNode $=307 \&$ CtUnit $=36 \&$ BaseD $\mathrm{SD}=7 \& \mathrm{mp}=2$, Retrieved on $28-05-$ 2011.

SPRING, "SPRINGnews - issues 2009 - 2010", www.spring.gov.sg/ Resources/Pages/SPRINGnewsarchives.aspx,retrieved on 22-06-2011.

Suresh D. deMel, (2011), "Keynote Speech on SME Sector", http://www.switch-asia.eu/fileadmin/ content/Colombo_sub_regional_event/F inance_session/Access_to_finance__Mr _Suresh-deMel.pdf, retrieved on $22-07$ $-2011$.

The Economic Times (2010), "Singapore set to be world's fastestgrowing economy in 2010", http://articles.economictimes.indiatimes. com/2010-07-14/news/27614029_1_ international-enterprise-domesticexports-song-seng-wun, retrieved on 15-06-2011.

The Electricity Act of 2009 and the Development of the Sector, 
http://sanvada.org/policyanalysis/sanvad a11_15/The\%20Impact\%20of\%20the\% 20New\%20Electricity\%20Act.pdf, retrieved on $18-06-2011$.

Tulus Tambunan (2001), "Development of SME in ASEAN with Reference to Indonesia and Thailand", Chulalongkorn Journal of Economics 20 (1), April 2008: $53 \quad-83$. http://www.econ.chula.ac.th/public/publ ication/journal/2008/cje200102.pdf, retrieved on 31 - $05-2011$.

UNDP (2007), "Malaysia Small and Medium Enterprises Building an Enabling Environment", http://www.undp.org.my/uploads/UND P_SME_Publication.pdf, retrieved on $28-05-2011$.

World Bank and the International Finance Corporation (IFC), "Doing Business 2011 - Making a Difference for Entrepreneurs - Singapore”, http://www.doingbusiness.org/ /media/ FPDKM/Doing\%20Business/Document s/Profiles/Country/DB11/SGP.pdf, retrieved on $15-06-2011$.
World Bank and the International Finance Corporation (IFC), "Doing Business 2011 - Making a Difference for Entrepreneurs - Sri Lanka", http://www.doingbusiness.org/ /media/ FPDKM/Doing\%20Business/Document s/Profiles/Country/DB11/LKA.pdf, retrieved on $15-06-2011$.

World Bank, "Sri Lanka Transport Sector", http://web.worldbank.org/ WBSITE/EXTERNAL/COUNTRIES/S OUTHASIAEXT/EXTSARREGTOPT RANSPORT/0,,contentMDK:20699037 $\sim$ menuPK:869140 pagePK:34004173 piPK:34003707 theSitePK:579598,00.h tml, retrieved in 29-09-2011.

World Economic Forum, "The Global Competitiveness Report", http://www3. weforum.org/docs/WEF_GlobalCompet itivenessReport_2010-11.pdf, retrieved on $12-06-2011$. 